\title{
Gender Differences in Educational Attainment: The Case of University Students in England and Wales
}

\author{
ROBERT MCNABB ${ }^{1}$, SARMISTHA PAL ${ }^{1}$, AND PETER SLOANE ${ }^{2}$
}

\begin{abstract}
This paper examines the determinants of gender differences in educational attainment using data for all graduates from universities in England and Wales in 1993. We find that although women students perform better on average than their male counterparts, controlling for a range of individual and institutional attributes, they are significantly less likely to obtain a first class degree. There is, however, no evidence that this arises either because of differences in the types of subjects male and female students study in the institutions they attend. Nor is there evidence that it reflects differences in personal attributes, such as academic ability. Rather it is differences in the way these factors affect academic achievement that give rise to gender differences in performance. In addition, although evidence is found of subjectspecific effects, there is no support for the idea that women under-perform in male dominated subject areas.
\end{abstract}

Key Words: educational attainment; gender; UK

JEL classification: I2, J7

${ }^{\prime}$ Economics Section

Cardiff Business School

Aberconway Building

University of Cardiff

Cardiff CF1 $3 E U$

${ }^{2}$ Department of Economics

Aberdeen University

Edward Wright Building 
Aberdeen AB24 3QY 


\section{Gender Differences in Educational Attainment: The Case of University Students in the England and Wales}

\section{INTRODUCTION}

During the past 25 years there has been a sharp increase in the participation of women in higher education. In 1975, women accounted for around one-third of university undergraduates in England and Wales, increasing to just under 40\% by 1990 . By 1999, just less than one half of the university undergraduate population were women. However, whilst the trend in participation has been towards greater equality, gender differences in degree are still significant. Historically, the general pattern is one of greater variation in the distribution of results for men than for women, and in particular, a significantly higher proportion of men than women achieving first class degrees (Table 1). On average, around 50 per cent more men than women achieve first class degrees, though at some universities the difference is much higher.

Gender differences in degree performance may arise for a number of reasons (Hoskins et al., 1997; Rudd, 1984). They may reflect differences in the types of subjects male and female students study or gender differences in individual-specific attributes that are correlated with attainment, such as family background, age and marital status. They may arise because of differences in the types and quality of the institutions male and female students attend. Additionally, gender differences in attainment could be due to psychological and/or biological factors (see, for example, Mellandy et al 2000). Finally, they may be the result of gender stereotyping and prejudice by a male dominated profession and which are manifest, inter alia, in the way students are assessed. Bradley (1984, 1993), for example, 
reports evidence of gender bias in the grading of students and suggests that some methods of assessment are more disadvantageous than others for women.

An understanding of the nature and determinants of gender differences in degree performance is, of course, important in itself. The significance of gender differences in degree performance also lies in the fact it is important as part of the wide-ranging examination of the structure and performance of the university system in the UK that has taken place in recent years including, most recently, by the Dearing Committee of Inquiry. ${ }^{1}$ Universities are now required to be more accountable in terms of the efficiency and effectiveness of the way in which they are managed and in the quality of the teaching they provide, including a commitment to equality of opportunity. Various indicators have been suggested as a basis upon which the performance of universities can be monitored and interinstitutional comparisons made, including measures of educational attainment such as degree results and drop-out rates (Johnes and Taylor, 1990; Johnes, 1992). Gender differences in degree results are therefore an integral feature of the scrutiny to which universities are now subject.

Gender differences in degree performance are also important because of the fact that educational attainment has an impact on labour market outcomes. The view that there is a glass ceiling to women's career progression in managerial and professional labour markets in the UK has received empirical support (Gregg and Machin, 1993; Jones and Makepeace, 1996; McNabb and Wass, 1997). Gender differences in labour market outcomes also reflect differences between men and women in the earnings-related attributes they bring to the labour market, including differences in educational achievement. Most studies of male-female earnings differentials in professional and managerial labour markets 
control for level of education but degree class or subject of degree are rarely, if ever, included. There is evidence, however, that not only degree but also degree classification impacts on earnings. Thus, Battu, Belfield and Sloane, (1999), report that a first class degree raises earnings by between 9 and 13 per cent six years after graduation relative to a lower second, which is more than twice the premium attaching to an upper-second degree. The fact that more men than women obtain a first class degree is therefore an important factor in the gender wage gap for graduates.

Although gender differences in educational attainment have attracted considerable attention and there is now a substantial literature on why such differences arise, the focus of much of this research has been on differences in performance at the primary and secondary school levels (See, for example, McDonald, Saunders and Benefield, 1999; Powney,1996). ${ }^{2}$ Analysis by economists to explain differential gender performance in higher education is especially limited (recent examples are, Blundell, Dearden, Goodman and Reed, 1997; Hoskins, Newstead and Dennis, 1997; Chapman, 1996a; Bartlett, Peel and Pendlebury, 1993). Moreover, evidence of a gender effect independent of other correlates of degree performance is ambiguous and statistically weak, though this often reflects deficiencies in the data used. As a result, inferences are made on the basis of only limited information on the other correlates of degree performance, making it difficult to identify the independent effect of gender. Many studies also only focus on a particular discipline, making it impossible to generalise to the wider student population.

The purpose of the present study is to provide a more comprehensive analysis of gender differences in educational attainment than has hitherto been possible. This is made possible because of the recent availability of a very rich data base taken from student 
records deposited with the Universities' Statistical Record (USR) by the 'old' universities in each year from 1973 to $1993 .^{3}$ The data base contain information for each student on a wide range of attributes including type of qualification obtained, class of degree, date of birth, marital status, A-level and/or Scottish Higher results, main entry qualification, parental occupation, type of school attended, subject of degree course and university attended. The latter variable can be used to construct a number of institution-specific variables that measure teaching quality and research intensity. ${ }^{4}$ The present study is therefore able to examine the validity of a number of hypotheses concerning the relationship between gender and educational attainment in the context of a comprehensive analysis of the determinants of academic performance.

The structure of the paper is as follows. In section 1 we present an overview of the main hypotheses that have been suggested to explain the relationship between gender and academic achievement. Section 2 provides a brief description of the data and highlights the main differences in the characteristics of male and female graduates. The empirical model to be estimated is described in Section 3 and the results are presented in section 4 . Conclusions and policy implications are discussed in section 5.

\section{GENDER AND DEGREE PERFORMANCE}

Several hypotheses have been suggested to explain gender differences in degree performance and in this paper we focus on a number of the more prominent ones (Hoskins et al., 1997; Rudd, 1984). However, one important explanation that we are not able to consider with the data available is that gender differences in academic attainment are due to psychological or biological factors. Gender differences have been found in such things as 
anxiety and examination stress, in self-efficacy and in the willingness to adopt risk-taking strategies in preparation for exams. However, these are not found to account for the gender gap in degree performance. Indeed, on some counts, such as motivation and work-effort questions, women score higher than men. (Mellanby et al, 2000).

One explanation for observed differences in attainment is that they are a compositional effect and reflect gender differences in the types of subjects studied and the fact that there are observed differences in the percentage of good degrees awarded across disciplines. Strictly speaking, if there were consistency in the application of academic standards across disciplines, subject-specific effects should be small or non-existent. The fact that there are significant variations in degree results by subject is, however, welldocumented (Nevin, 1972; Bee and Dolton, 1985; Johnes and Taylor, 1990). These may arise because of differences in the type of subject material, with students in more quantitative subjects being more able to achieve very high or very low exam marks. There may also be an element of custom and practice whereby disciplines have, over time, established rather different standards.

One reason commonly put forward for why the distribution of students by subject area is different by gender is that the relative scarcity of female faculty in traditionally male disciplines has contributed to the reluctance of females to study in those disciplines. However, this hypothesis has found little empirical support (see, for example, Canes and Rosen, 1995 and Solnick, 1995) though Rothstein (1995) has found that the percentage of faculty who are female in an institution is significantly associated with the probability that female students obtain an advanced degree. 
Table 3 presents the distribution of degree classifications by discipline together with the proportion of female students in each subject group. ${ }^{5}$ Clearly, the distribution of degree results is very different across the different disciplines with physical sciences, engineering and technology and mathematical sciences having proportionately more firsts than is found in other subject areas. These are also the subject groups with the smallest proportion of female students. In the empirical analysis, a series of subject dummy variables are used to control for differences in the distribution of females across disciplines.

A second explanation for observed gender differences in attainment is that they reflect differences in academic aptitude. The suggestion is that the variation in ability is greater for men than it is for women and that this explains why male students are more likely to be found at the extremes of the distribution of degree attainment (Holdstock, 1998). Ability is, however, notoriously difficult to measure though A-level (or Scottish Higher) scores are often used as a proxy (Johnes and Taylor, 1990). In the absence of any alternatives in the data used in the present study, gender differences in academic ability will be measured using A-level score. ${ }^{6}$ Two approaches are used in the empirical analysis. First, the gender effect on degree performance is estimated net of ability by including ability (as proxied by A-level/Scottish Higher score) in the models to be estimated. Second, we estimate predicted degree performance probabilities for students with maximum Alevel/Scottish Higher level scores. This provides an alternative estimate of the gender effect for students who are more homogenous in terms of academic ability.

A further reason for gender differences in degree performance is that they reflect gender-related biases in assessment. This may arise because of differences in the way male and female students respond to different types of assessment - it is suggested, for example, 
that male students perform better in exams and worse in continuous assessment than female students. Alternatively, it could be due to prejudice and gender stereotyping by male staff. It is, however, difficult to test this hypothesis with the data currently available. ${ }^{7}$ However, if gender-related bias and prejudice do exist and vary by subject area, one indirect test of this hypothesis would be to investigate whether, other things equal, the gender gap in attainment is different across academic disciplines and whether it is larger in subjects that are maledominated. Although such an analysis can only be suggestive of bias, it nevertheless provides some indication of the extent to which prejudice contributes to the gender difference in degree performance.

Finally, gender differences in degree performance may reflect differences that exist between institutions either in the extent to which they award first class degrees (possibly reflecting differences in the quality of institutions) or in the extent to which female students are disadvantaged across institutions. First, the impact of teaching quality and research intensity on student degree attainment is considered. It has been suggested that universities have promoted and valued research at the expense of teaching quality. Indeed, the Dearing Report comments that, 'one current barrier is that staff perceive national and institutional policies as actively encouraging and recognising excellence in research, and not in teaching' (The National Committee into Higher Education, Main Report, page 115). The present study will seek to examine this proposition, at least in terms of establishing how teaching quality and research intensity affect academic attainment.

We include one direct measure of teaching quality and three variables that are inputs into the teaching process and are expected to enhance teaching quality. The direct measure is the percentage of departments graded as "excellent" in teaching quality assessments. One 
would expect that universities that score highly in terms of teaching quality assessments are more able to produce a better quality output for a given level of inputs. The three other measures of teaching quality used are total university expenditure per student, library expenditure per student and the staff-student ratio. Both expenditure measures are indicative of the resources available to students and are expected to improve the likelihood of obtaining a good degree. Students at universities with high staff-student ratios may receive more personal tuition and better pastoral care, both of which are expected to improve degree performance.

The measure of research intensity that we consider is the percentage of a university's total income that comes from research grants and contracts. It is expected that universities in which there is a high standard of research will attract better staff, provide a more stimulating environment for their students, and, as a result, attract more able students.

The last institutional variable included is a measure of size. The effect of size on student performance is unclear. Smaller universities may provide better personal tuition and pastoral care thus improving students' prospects of obtaining a good degree. However, larger universities may be better resourced and attract better staff, both of which could increase the likelihood of getting a good degree. We use the number of undergraduates at the university as the possible measure of size of the institution.

In addition to examining the hypotheses of primary interest we have also controlled for a number of other potential correlates of degree performance some of which may give rise to gender related differences in degree performance. First, family background, as measured by parental occupation, may affect student degree attainment if students from lowincome families are less well resourced and are thus less able to afford the purchase of 
books and other materials and equipment. They may also need to spend more time in nonacademic work in order to supplement their income, thereby detracting from their studies and lowering their level of achievement. Students from professional and managerial family backgrounds may also be better able to 'work the system' and be more likely to approach academic staff when they are facing difficulties in their studies.

Students born outside the UK may be at a disadvantage over those born in the UK if English is not their first language and/or they are less familiar with the university system and methods of assessment. This could be offset if overseas students are more highly motivated and willing to work harder especially if they or their parents are responsible for tuition fees.

Also included in the analysis is the age and marital status of the student. One might expect older students and those who are married to have more initiative, self-reliance and motivation than single students and those who have come to university straight from school. Married students may, however, have domestic commitments which limit the amount of time spent studying and older students may find the transition back to full-time education difficult especially if they did not do well academically first time around.

Two variables are included in this respect. The first is the type of school attended, which could affect degree performance in a number of ways. The private sector may provide a higher quality of education than is available in the state sector due to being better resourced. As a result, students from private schools may achieve higher average A level/Higher grades compared with students from state schools with the same level of innate ability. Once entry into university has been achieved, however, students from private schools may perform less well than their counterparts from state schools holding constant Alevel/Higher scores. On the other hand, private schools may provide their students with 
other skills, including social skills, which enable students to adapt better to university life thereby raising degree performance, other things equal.

Also included is the main entry qualification that was used to obtain admission to university. This will enable us to examine whether students who enter with no formal educational qualifications or with qualifications other than A-levels/Highers are at a disadvantage and do not perform as well as students with conventional academic prerequisites. Such students may be less academically inclined or may find full-time education more arduous than students who enter university on the basis of their A-level/Scottish Higher results.

\section{DATA}

The USR data used in the paper contains information on all graduates who left university in 1993. For the purposes of the present study, students of medicine and dentistry, most of whose degrees are not graded in terms of the classification that is standard in other subjects, are excluded. We also confine our analysis to students at universities in England and Wales. We decided to exclude individuals at Scottish universities due to the distinctive nature of Scottish higher education, which makes direct comparisons difficult. First, a majority of students in Scotland enter with School Higher qualifications, taken one year after GCSEs, rather than Alevels, as in England and Wales, which are usually taken two years after GCSEs, and study for honours degrees lasting four years as opposed to three. However, approximately 30 per cent of students in Scotland choose to graduate after three years with non-honours ordinary or general degrees, which do not represent failed honours as is usually the case in England and Wales. As a result, the classifications of degree results are not 
strictly comparable. Secondly, while research assessments have been made across the UK, Scotland applies a different system than England and Wales for assessing teaching quality.

The analysis is also restricted to students for whom this was their first undergraduate degree therefore excluding those who were already graduates in another discipline.

Table 2 summarises the covariates that determine degree performance separately for male and female students. The table shows that male graduates entered university with marginally better A-level scores and, among those whose main entry qualification is not Alevels, were more likely to have some other form of formal educational qualification. There is little difference between male and female students in terms of the type of school attended: over half of all university students graduating from universities in England and Wales in 1993 came from comprehensive schools with about one quarter being drawn from independent schools.

Not unexpectedly, a very high proportion of university students (around 60 per cent) come from professional or managerial family backgrounds with less than 15 per cent having parents with manual occupations. There are some small differences in the parental background of male and female students. The proportion of female students whose parents are in professional and managerial occupations is higher than that for the male-student population and the proportion of students with parents in manual occupations is smaller amongst female students.

There are significant gender differences in the subjects studied at university. Broadly speaking, female students are more likely to graduate with a degree in creative arts, languages and related subjects, or in one of the social sciences. On the other hand, they are considerably less likely to graduate in engineering and technology or in mathematical and 
physical sciences. The average age of male and female graduates is about the same and around 3 per cent of female students are married compared with just less than 2 per cent of male students.

Finally, there are some differences in the types of institutions male and female students attend. On average, female students are in universities with lower levels of income and expenditure per student and with lower library expenditure and research income. The average level of teaching and research quality is slightly lower for female students than it is for male students.

\section{EMPIRICAL FRAMEWORK}

\section{Measuring Educational Attainment}

Educational attainment is measured in terms of class of degree, which in the USR data is ordered on a 12 point scale. To make the econometric analysis manageable, and because a number of the categories contain only a small number of observations, the USR scale was condensed as follows: $5=$ first class honours; $4=$ upper second class honours; $3=$ lower second class honours plus undivided second class honours; $2=$ third class honours plus unclassified honours; $1=$ pass degree plus ordinary degree plus general degree; $0=$ fail/drop-outs. Students who graduated with an aegrotat degree or with an enhanced first degree (Masters) were not included in the analysis. There are also a small number of graduates whose degree classification is not known. Given the ordered nature of the degree class variable, a natural choice is to estimate an ordered probit model.

Measuring academic performance using degree results implicitly assumes comparability in degree standards across disciplines and/or universities. The assumption that 
the degree classification is applied in a uniform way has long been a basic premise of the UK university system though it is one that has been called into question in recent years (Silver et al, 1995). Although we consider only pre-1992 universities, where there may be greater consensus about standards, the possibility that there are differences in the way degrees are awarded by institution and by discipline cannot be ruled out. The inclusion of subject studied and the various institutional variables will capture differences in standards and therefore reduce the bias this may introduce into the estimated gender effect.

\section{Measuring the Impact of Gender}

The male and female distributions of students by degree results shown in Table 1 highlight the fact that although women, on average, perform better than their male counterparts, they are underrepresented amongst those students who achieve the best degree results. To measure the impact of gender on educational attainment, separate ordered probit models are estimated for male and female graduates. These are then used to investigate whether the gender effect in terms of average degree performance arises because of differences between male and female students in ability, subject mix and the other correlates of degree performance. This analysis uses a variant of the Oaxaca-type decomposition proposed by Jones and Makepeace (1996).

The methodology used in this decomposition analysis is as follows. Using the ordered probit model, we determine the probability of achieving a particular degree class, $d$, separately for male and female samples, characterised by some average characteristics, $X_{m}$ and $X_{f}$ respectively. Suppose $\left[\operatorname{Pr}\left(\mathrm{d}, X_{i}, \theta_{i}^{*}\right)\right]$ is the expected probability of any degree classification, $d$, for a typical individual characterised by $X_{m}$ or $X_{f}$, where $\theta_{i}^{*}$ is the vector of 
maximum likelihood estimates of the parameters of the ordered probit model for the $i$-th sample, with $i=m, f$, for male and female samples respectively. Therefore, the expected grades for the typical individual would be given as follows,

$$
\begin{aligned}
d_{m}^{*} & =\sum_{d=0}^{1} d \operatorname{Pr}\left(d, X_{m}, \boldsymbol{\theta}_{m}^{*}\right) \\
d_{f}^{*} & =\sum_{d=0}^{1} d \operatorname{Pr}\left(d, X_{f}, \boldsymbol{\theta}_{f}^{*}\right)
\end{aligned}
$$

Using these expected grades for male and female samples respectively, one can decompose the male-female differential in degree performance as follows,

$$
\begin{aligned}
& d_{m}^{*}-d_{f}^{*}=\sum_{d=0}^{1}\left[\operatorname{Pr}\left(d, X_{m}, \boldsymbol{\Theta}_{m}^{*}\right)-\operatorname{Pr}\left(d, X_{f}, \boldsymbol{\Theta}_{m}^{*}\right)\right]+\sum_{d=0}^{1} d\left[\operatorname{Pr}\left(d, X_{f}, \boldsymbol{\Theta}_{m}^{*}\right)-\operatorname{Pr}\left(d, X_{f}, \boldsymbol{\Theta}_{f}^{*}\right)\right] \\
& d_{m}^{*}-d_{f}^{*}=\sum_{d=0}^{1} d\left[\operatorname{Pr}\left(d, X_{m}, \boldsymbol{\theta}_{f}^{*}\right)-\operatorname{Pr}\left(d, X_{f}, \boldsymbol{\theta}_{f}^{*}\right)\right]+\sum_{d=0}^{1} d\left[\operatorname{Pr}\left(d, X_{m}, \boldsymbol{\theta}_{m}^{*}\right)-\operatorname{Pr}\left(d, X_{m}, \boldsymbol{\theta}_{f}^{*}\right)\right]
\end{aligned}
$$

In both equations (2) and (3), the first summation holds the estimated parameters constant but allows individual, subject and institutional characteristics to vary, giving two values for the explained variation attributable to the different characteristics of male and female students. The terms in the second summation hold individual, subject and institutional characteristics constant, but allow the parameters to vary and therefore measure the unexplained variation attributable to the different treatment of male and female students in the university system.

For the ordered probit model, estimated coefficients do not reflect their marginal effects and although marginal effects can be calculated these are not meaningful for discrete explanatory variables (Greene, 2000) In a second analysis therefore the ordered probit coefficients are used to derive a number of predicted degree performance probabilities. 
These show the likelihood of achieving different degree results using a particular set of observed characteristics (if continuous) or for the values 1, 0 (if discrete) keeping other covariates at their mean values. The predicted probability of obtaining a particular degree for average male and female students are estimated from the male and female ordered probit coefficients using the following formulae:

$$
\begin{aligned}
& \operatorname{Prob}[\mathrm{d}=0]=\Phi\left(-\mathrm{X}^{\prime} \beta\right) \\
& \operatorname{Prob}[\mathrm{d}=1]=\Phi\left(\mu_{1}-\mathrm{X}^{\prime} \beta\right)-\Phi\left(-X^{\prime} \beta\right) \\
& \operatorname{Prob}[\mathrm{d}=2]=\Phi\left(\mu_{2}-\mathrm{X}^{\prime} \beta\right)-\Phi\left(\mu_{1}-X^{\prime} \beta\right) \\
& \operatorname{Prob}[\mathrm{d}=3]=\Phi\left(\mu_{3}-\mathrm{X}^{\prime} \beta\right)-\Phi\left(\mu_{2}-\mathrm{X}^{\prime} \beta\right) \\
& \operatorname{Prob}[\mathrm{d}=4]=\Phi\left(\mu_{4}-\mathrm{X}^{\prime} \beta\right)-\Phi\left(\mu_{3}-\mathrm{X}^{\prime} \beta\right) \\
& \operatorname{Prob}[\mathrm{d}=5]=1-\Phi\left(\mu_{4}-\mathrm{X}^{\prime} \beta\right)
\end{aligned}
$$

where $\Phi$ is the cumulative normal distribution function such that the sum total of all these probabilities is equal to one. These predicted probabilities are used to study gender differences in degree performance by academic aptitude, subject area and institutionspecificfactors.

\section{RESULTS.}

\section{The determinants of degree performance}

Before considering the main findings of the empirical analysis, two sources of bias are noted. First, the analysis undertaken here only considers students who started at university and excludes those who do not go to university, either through choice or because they did not 
obtain the necessary qualifications. A recent study by Leslie and Drinkwater (1999), however, suggests that there are very few gender differences in the determinants of participation in higher education. The fact that we have not controlled for non-participation should not therefore affect the estimates of the gender effect presented here. A second potential source of bias is self-selection by subject. If female students are generally less inclined to enter the sciences and engineering, those who do so may be more motivated or able in these subjects than their male counterparts. Unfortunately, we are not able to model the subject choice decision though we are able to control for differences in the distribution across disciplines by gender.

Estimates of the ordered probit model of academic attainment for male (column 1) and female (column 2) students are shown in Table 4. Before considering the implications of the results in the context of the main concern of the paper, a number of interesting relationships between degree performance and observed characteristics are briefly highlighted. First, academic aptitude, as proxied by A-level and Higher-level scores, is found to have a strong positive effect on degree attainment. Type of school attended also affects student achievement over and above the effects of A-level /Higher level score. The results indicate that students who come to university from comprehensive schools perform better, on average, than those who attended other types of school. The differential is largest compared with students from independent schools. This lends support to the idea that students from private schools have an advantage over those from state schools in gaining admission to university because they are able to achieve higher average A-level grades for a given level of student quality. It also suggests that consideration should be given to this when 
formulating university admissions policy and lends some support, at least, for policies aimed at increasing access to university.

However, students with no formal qualifications or GCE are less likely to do better at university, holding constant the other covariates, than students whose main entry qualification is A-levels or some other form of educational qualification, such as HND or the Certificate in Education.

The results also indicate that mature students do better than younger ones though the relationship between age and academic performance is concave and age has a negative impact on performance for those aged 35 years and over. Married students have lower levels of academic achievement compared with single students, presumably due to their greater domestic commitments.

Students born outside the UK are more likely to do well compared to those born in the UK, however, the effect is insignificant. Students whose parents are in managerial and professional occupations are at an advantage over those from other socio-economic backgrounds, namely, those in jobs related to clerical, personal services, manual and others (not specified category).

It is clear that significant differences remain in the spread of results by subject even after controlling for students' individual attributes and pre-higher education and higher education institutional characteristics and that these effects vary by gender. In particular, the distribution of degree results across the degree classification is, on average, less favourable in agriculture and veterinary sciences, physical sciences, mathematical sciences, engineering and technology than in business administration and finance subjects (the reference group). Male student performance is also porer in the social sciences and in architecture and 
related studies but this is not the case for female students. Female students in humanities are found to perform better than those in the reference group whereas male students are found to do worse, on average. Students graduating in biological sciences and languages and mass communications and information sciences perform on a par with those in the reference group, other things equal.

As for university-related variables, the findings are, first, that higher research income and teaching quality have a strong positive impact on male student achievement. This raise some doubt about the view that research assessment exercises have led staff to neglect their teaching duties in favour of pursuing their research interests as implied by the Dearing Report. A strong research record also enhances female attainment, though teaching quality does not appear to have an effect. In addition higher staff-student ratio and library expenditure (per student) are found to increase student performance significantly. However, higher total expenditure per student does not necessarily enhance academic achievement while higher student numbers seem to have an insignificant effect on academic achievement.

\section{Explaining gender differences in degree results}

The results shown in Table 4 are used to obtain the predicted probabilities that male and female students achieve different degree results. These predicted probability estimates are shown in Table 5. The results show that the likelihood that female students get a first is 5 per cent compared with 8 per cent for male students. ${ }^{8}$ What is interesting about the results, however, is that when the male equation is used to predict the probability of getting a first for female students, using mean female attributes, the probability of a female student achieving a first increases to 7.3 per cent. Indeed, the distribution of predicted degree results for female 
students based on the male ordered probit results mirrors that for male students using the same set of coefficients.

Similarly, when the estimated coefficients from the female equation are used to predict the distribution for male students, using the mean male attributes, it is found to be almost identical to that for female students based on the same set of coefficients. Gender differences in degree performance, including the likelihood of getting a first, thus have less to do with gender differences in individual, subject or institutional attributes but almost entirely reflect differences in the way these attributes impact upon performance.

The results of the decomposition exercise (Table 6) provide further support for the notion that differences in attributes are relatively insignificant in explaining gender differences in educational attainment with only 21 per cent of the gender gap in attainment being due to differences in male and female characteristics.

It seems clear therefore that gender differences in educational attainment have little to do with differences in characteristics. We now consider the primary hypotheses outlined earlier, namely whether differences in academic aptitude, bias or prejudice in assessment, and institution-specific factors contribute to observed gender differences in educational attainment. This is done by computing the predicted degree performance probability distributions for male and female students by A-level score, subject categories and institution-specific characteristics.

Table 7 presents the predicted degree performance probabilities calculated for students with maximum A-level (or Scottish Higher) points, with the other covariates taking their mean values. As the table shows, the most academically able students are significantly more likely to obtain better degrees, other things equal. However, a much smaller 
proportion of female students are predicted to achieve first class degrees. Notwithstanding the fact that A-level score is an imperfect measure of academic aptitude, the results suggest that even amongst the more able students, females continue to be under-represented at the top end of the degree performance distribution. Differences in measured academic ability therefore cannot account for the observed gender differences in educational attainment amongst university students in England and Wales.

Turning now to the impact of subject area on the distribution of results. To investigate whether there are subject-specific effects, independent of the effects of the other covariates, the predicted probability distribution of degree results are estimated for each subject area with the other covariates again taking their gender-specific mean values. The results (shown in Table 8) illustrate a number of important features about subject-specific effects. First, there is a considerable degree of consistency in the results for male students in the sense that, holding other things constant, the probability of a male student achieving a first class degree does not vary very much by subject area. The three exceptions are agriculture and veterinary sciences, architecture and related subjects and education, all of which account for only a small fraction of the student population. The subject-specific effects for female students, on the other hand, show more variation with the likelihood of obtaining a first class degree highest in creative arts, business and finance and in education and related studies. They are significantly lower in mathematical sciences, architecture and related subjects and in agriculture and veterinary sciences.

There is, however, little evidence that female students under-perform more in maledominated subjects such as the sciences and engineering, which casts some doubt on the notion that bias and male prejudice significantly reduce the likelihood of female students 
achieving first class degrees. Although it is the case that the few subject areas in which the likelihood of getting a first is higher for women than it is for men are also subjects that have a high percentage of female students, there are a number of male-dominated subjects in which the gender gap is relatively small. The final feature of the results highlighted here is that, other things equal, female students are less likely to achieve a first class degree in nearly all subject areas though the size of the gender gap does vary by subject area. These results suggest that subject-specific effects do contribute to the gender wage gap but that they are not linked in a significant way to whether a subject area is male-dominated.

Finally, we examine whether the extent of the gender gap in educational attainment varies across universities. Table 9 and 10 show the expected probability distribution of degree results by university calculated for the institution-specific values of the institutional variables and the mean values of the other covariates. That we are unable to name specific universities limits the sorts of comments that can be made to more general statements about university-specific effects. Notwithstanding this, a number of important findings are evident in the results. First, there is more consistency in the predicted probabilities of degree results than is the case in the actual data. Focusing on the likelihood of achieving a first class degree, the ratio of the percentage of males to females by university with first class degrees based on the predicted probabilities has a mean of 1.63 and standard deviation of 0.177 . This compares with a mean of 1.47 and standard deviation of 0.331 for the actual ratio of the percentage of males to females achieving firsts by university. Second, nearly all those universities that award relatively more firsts to men than to women are also found to have high ratios of the predicted probabilities for men and women. In other words, the fact that women significantly under-perform in some universities cannot fully be explained by such 
things as subject mix, academic aptitude and the other observables we have controlled for. Indeed, there are a number of universities in which the university-specific effect works against such things as subject mix with the result that women do proportionately worse than would be expected on the basis of other observables. Finally, there is only a weak relationship between the proportion of firsts awarded by a university and the gender gap between male and female students - the correlation coefficient between the proportion of firsts awarded (either male or female) and the gender gap is 0.276 and is not significantly different from zero.

\section{CONCLUSIONS}

Gender differences in degree performance are striking, but little understood. In this paper we have explored the relationship between gender and academic achievement controlling for various personal and institutional attributes. Overall, women are less likely than male students to get a first class degree but are more likely to graduate with an upper second. In this paper we have investigated why academic achievement differs by gender and, in particular, why female students are less likely to achieve first class degrees. Our findings indicate, first, that differences in such things as subject mix and individual and institutional characteristics cannot explain the gender gap in achievement to any significant degree. An important conclusion of the analysis is that gender differences in academic achievement arise because of differences in the way these attributes impact upon performance.

A number of possible explanations for these differences were then considered. These focused on differences in academic ability, male bias or prejudice in the way students area assessed and institution-specific factors. The results provide no support for the 
hypothesis that differences in academic aptitude contribute to gender differences in educational achievement. Even amongst the most academically able students, a gender gap in performance at the top end of the distribution persists, other things equal.

Neither is there support for the hypothesis that male prejudice or bias systematically acts against female students. Although there is evidence of subject-specific-effects that impact upon the likelihood of female students achieving first class degrees, it is not the case that female students are especially disadvantaged in male-dominated subject areas. Finally, there is some evidence that institution-specific factors affect the likelihood of achieving a good degree, though they are not able to account for the gender differences in performance.

The fact that the results presented in the paper suggest that academic aptitude, subject-specific factors and institutional attributes do not account for much of the gender difference in academic performance possibly suggests that such differences arise for reasons that are gender-specific. However, although Mellanby et al (2000) find gender differences in a range of psychological variables (including anxiety and examination stress and in the types of strategies adopted in exams) they are not responsible for the gender gap in degree performance. This would seem to suggest that the explanation for gender differences in academic performance is complex and involves interactions between the different hypotheses rather than reflecting one particular set of considerations.

\section{AKNOWLEDGEMENTS}

The authors would like to thank Wiji Arulampalan, Geraint Johnes, Gerry Makepeace, David Peel and Helen Robinson for comments and suggestions and Richard Jones for excellent research assistance. The authors are also grateful to the depositors of the data and 
the ESRC Data Archive for permission to use it and making it available to us. The usual disclaimer applies. 


\section{REFERENCES}

Bartlett, S., Peel M.J. and Pendlebury M. (1993). 'From fresher to finalist: A three year analysis of student performance on an accounting degree programme.', Accounting Education, vol. 2, pp. 111-122.

Battu, H., Belfield, C. R and Sloane, P. J (1999) 'Over-education Among Graduates: A Cohort View', Education Economics, vol. 7, pp. 21-38.

Bee, M. and Dolton P. (1985). 'Degree class and pass rates: An inter-university comparison', Higher Education Review, vol. 17, pp. 45-52.

Bourner, T. and Hamed, M. (1987). Entry Qualifications and Degree Performance, London, Council for National Academic Awards.

Bradley, C. (1984). 'Sex bias in the evaluation of students', British Journal of Social Psychology, vol. 23, pp. 147-153.

Bradley, C. (1993). ‘Sex bias in evaluations at college and work: A comment on Archer's review.' The Psychologist, vol. 6, pp. 152-154.

Canes, B. J. and Rosen, H. S. (1995) 'Following in her Footsteps? Faculty Gender Composition and Women's Choices of College Major, Industrial and Labor Relations Review, vol. 48, pp 486-504 
Chapman, K. (1995). 'Geography degrees and gender: Patterns and possible explanations.' Area, vol. 27, pp. 62-73.

Chapman, K. (1996a). 'An analysis of degree results in geography by gender.' Assessment and Evaluation in Higher Education, vol. 21, pp. 293-311.

Chapman, K. (1996b). 'Entry qualifications, degree results and value-added in UK universities.' Oxford Review of Education, vol. 22, pp. 251-64.

Dolton, P. Greenaway D. and Vignoles A. (1997). 'Whither higher education? An economic perspective for the Dearing Committee Inquiry.' Economic Journal, Vol. 107, pp. $710-726$.

Greene, W. H., (2000) Econometric Analysis, (4 ${ }^{\text {th }}$ edition) Prentice-Hall, New Jersey.

Gregg P. and Machin S. (1993). 'Is the glass ceiling cracking?: Gender pay differences and access to promotion among UK executives.' (mimeo) LSE Centre for Economic Performance.

Hanushek E.A. (1979). 'Conceptual and empirical issues in the estimation of educational production functions.' Journal of Human Resources, vol. 15, pp. 351-88. 
Higher Education Quality Council (HEQC) (1996). Inter-institutional Variability of Degree Results: An Analysis of Selected Subjects, London.

Holdstock, L (1998). 'The Ratio of Male to Female Undergraduates' in, J Radford (ed) Gender and Choice in Education and Occupation, Routledge, London.

Hoskins, S., Newstead, S., and Dennis, I., (1997). ' Degree Performance as a Function of Age, Gender, Prior Qualifications and Discipline Studied', Assessment \& Evaluation in Higher Education, vol. 22, pp. 317-328.

Johnes, G. (1992). 'Performance indicators in higher education: A survey of recent work.' Oxford Review of Economic Policy, vol. 8, pp. 19-34.

Johnes, G. (1997). 'Costs and industrial structure in contemporary British higher education.' Economic Journal, vol. 107, pp. 727-737.

Johnes, J. and Taylor, J. (1990). 'Performance Indicators in Higher Education', The Society for Research into Higher Education and Open University Press, Buckingham.

Jones, D. and Makepeace, G. (1996). 'Equal worth, equal opportunities: Pay and promotion in an internal labour market.' Economic Journal, vol. 106, pp. 401-409. 
Martin, M. (1997) 'Emotional and Cognitive Effects of Examination Proximity in Female and Male Students', Oxford Review of Education, vol. 20, pp. 479-486.

McDonald, A., Saunders, L. and Benefield,P. (1999) 'Boy's Achievement, Progress, Motivation and Participation: Issues Raised by the Recent Literature', The National Foundation for Educational Research, Slough, Berks, March

McNabb, R. and Wass, V. (1997). 'Male-female salary differentials in British universities.' Oxford Economic Papers, vol. 49, pp. 328-343.

Mellanby, J., Martin, M., and O'Doherty,. J. (2000). The 'Gender Gap' in Final Examination results at Oxford University', British Journal of Psychology, vol. 91, pp. 377-390.

The National Committee into Higher Education (1997) Higher Education in the Learning Society, Report of the National Committee, HMSO, London.

Nevin, E. (1972). 'How not to get a first.' Economic Journal, vol. 82, pp. 658-673.

Powney, J. (1996) 'Gender and Attainment: A Review’, Scottish Council for Research in Education, SCRE Research Report No. 81, December, Edinburgh

Rothstein, D. S. (1995) 'Do Female Faculty Influence Female Students Educational and Labour Market Attainment'? Industrial and Labor Relations Review, vol. 48, pp 515-530. 
Rudd, E., (1984). ' A Comparison between the Results Achieved by Women and Men Studying for First Degrees in British Universities', Studies in Higher Education, vol. 9, pp. $47-93$.

Silver, H, Stennett, A. and Williams, R. (1995). The External Examiner System: Possible Futures, Higher Education Quality Council, London.

Solnick S. J. (1995) 'Changes in Women's Majors from Entrance to Graduation at Women's and Co-educational Colleges', Industrial and Labor Relations Review, vol. 48, pp 505-514. 
TABLE 1

THE DISTRIBUTION OF DEGREE RESULTS BY GENDER, 1993

\begin{tabular}{|c|c|c|}
\hline & Male students & Female students \\
\hline First Class & 11.3 & 7.4 \\
\hline Upper second & 40.8 & 51.4 \\
\hline Lower Second & 34.9 & 34.3 \\
\hline Third Class & 8.6 & 4.2 \\
\hline Pass, other degrees & 4.5 & 3.7 \\
\hline
\end{tabular}


TABLE 2.

DESCRIPTIVE STATISTICS

\begin{tabular}{|c|c|c|c|c|}
\hline & \multicolumn{2}{|c|}{ Male students } & \multicolumn{2}{|c|}{ Female students } \\
\hline & Mean & Std. Deviation & Mean & Std. Deviation \\
\hline Age & 23.325 & 4.446 & 23.886 & 5.715 \\
\hline Married & 0.033 & 0.180 & 0.064 & 0.240 \\
\hline \multicolumn{5}{|l|}{ School Type } \\
\hline Others & 0.170 & 0.380 & 0.190 & 0.390 \\
\hline Tech & 0.018 & 0.130 & 0.019 & 0.140 \\
\hline Comprehensive & 0.400 & 0.490 & 0.390 & 0.490 \\
\hline Grammar & 0.096 & 0.290 & 0.100 & 0.300 \\
\hline Independent & 0.230 & 0.420 & 0.200 & 0.400 \\
\hline Sixth Form College & 0.090 & 0.290 & 0.096 & 0.290 \\
\hline A Level Score & 17.520 & 10.170 & 16.760 & 9.940 \\
\hline Scotish Highers & 0.076 & 0.920 & 0.086 & 0.980 \\
\hline (av. for those taking Highers) & 9.110 & 4.280 & 9.170 & 4.390 \\
\hline \multicolumn{5}{|l|}{ Main Entry Qualification } \\
\hline A-levels & 0.800 & 0.400 & 0.800 & 0.400 \\
\hline Other Qualifications & 0.108 & 0.312 & 0.080 & 0.354 \\
\hline No Formal Qualifications & 0.092 & 0.290 & 0.110 & 0.310 \\
\hline Born in the UK & 0.860 & 0.350 & 0.870 & 0.340 \\
\hline \multicolumn{5}{|l|}{ Parental Occupation } \\
\hline Professional \& Managerial & 0.540 & 0.500 & 0.550 & 0.500 \\
\hline Clerical & 0.079 & 0.270 & 0.077 & 0.270 \\
\hline Personal Services & 0.066 & 0.250 & 0.056 & 0.230 \\
\hline Skilled Manual & 0.003 & 0.055 & 0.003 & 0.053 \\
\hline Unskilled & 0.210 & 0.240 & 0.126 & 0.277 \\
\hline Not specified & 0.170 & 0.370 & 0.200 & 0.400 \\
\hline \multicolumn{5}{|l|}{ Subject } \\
\hline Languages & 0.074 & 0.262 & 0.205 & 0.404 \\
\hline Information Sciences & 0.002 & 0.041 & 0.006 & 0.076 \\
\hline Mathematical Sciences & 0.113 & 0.317 & 0.052 & 0.221 \\
\hline Subjects related to medicine & 0.019 & 0.135 & 0.044 & 0.206 \\
\hline Multi-discipline & 0.045 & 0.207 & 0.057 & 0.232 \\
\hline Physical Sciences & 0.127 & 0.333 & 0.065 & 0.247 \\
\hline Architecture \& Related & 0.016 & 0.124 & 0.008 & 0.087 \\
\hline Creative Arts & 0.016 & 0.124 & 0.030 & 0.170 \\
\hline Biological Science & 0.066 & 0.249 & 0.108 & 0.311 \\
\hline Agriculture \& Veterinary Sciences & 0.012 & 0.111 & 0.014 & 0.118 \\
\hline Business/Finance & 0.058 & 0.233 & 0.054 & 0.226 \\
\hline Education & 0.006 & 0.080 & 0.020 & 0.141 \\
\hline Engineering \& Technology & 0.180 & 0.384 & 0.036 & 0.188 \\
\hline Humanities & 0.074 & 0.263 & 0.086 & 0.280 \\
\hline \multicolumn{5}{|l|}{ Institutional variables } \\
\hline RAE Ranking & 24.620 & 15.190 & 25.680 & 15.120 \\
\hline $\begin{array}{l}\text { Percentage of income from } \\
\text { research contracts/grants }\end{array}$ & 17.878 & 7.008 & 17.057 & 6.860 \\
\hline Expenditure Per Student & 13.840 & 4.328 & 13.223 & 3.800 \\
\hline Income per student & 14.375 & 4.399 & 13.739 & 3.898 \\
\hline Library spending per student & 0.426 & 0.219 & 0.410 & 0.202 \\
\hline $\begin{array}{l}\text { Percentage of departments graded } \\
\text { 'excellent' in TQA }\end{array}$ & 45.369 & 20.290 & 43.790 & 19.543 \\
\hline Number of cases & \multicolumn{2}{|c|}{40849} & \multicolumn{2}{|c|}{33666} \\
\hline
\end{tabular}


TABLE 3

DISTRIBUTION OF DEGREE PERFORMANCE BY SUBJECT AND PERCENTAGE OF FEMALE STUDENTS

\begin{tabular}{|l|ccccccc|}
\hline \multicolumn{1}{|c|}{ Subject Area } & Female (\%) & First & Two-one & Two-two & Third & Other & $\begin{array}{c}\text { Non- } \\
\text { completion }\end{array}$ \\
\hline Agriculture \& & 48.3 & 3.8 & 32.6 & 27.8 & 3.9 & 22.0 & 9.9 \\
Veterinary Sciences & & & & & & & \\
Architecture \&related & 28.5 & 7.9 & 35.0 & 27.3 & 4.8 & 4.2 & 20.8 \\
Creative Arts & 61.3 & 6.3 & 40.6 & 25.5 & 3.6 & 1.1 & 22.8 \\
Biological Science & 57.3 & 7.2 & 45.6 & 30.3 & 4.2 & 1.1 & 11.6 \\
Business/Finance & 43.6 & 6.0 & 43.4 & 29.3 & 3.5 & 4.2 & 13.8 \\
Education & 72.1 & 2.8 & 31.4 & 23.5 & 1.9 & 10.7 & 29.6 \\
Engineering \& & 14.3 & 12.0 & 27.3 & 29.6 & 10.7 & 5.9 & 14.4 \\
Technology & & & & & & & \\
Humanities & 48.7 & 6.6 & 47.8 & 29.0 & 2.3 & 2.6 & 11.6 \\
Languages & 69.5 & 7.5 & 47.3 & 29.0 & 2.4 & 1.2 & 12.6 \\
Information Sciences & 74.2 & 4.5 & 51.5 & 27.3 & 3.4 & 4.2 & 9.1 \\
Mathematical Sciences & 27.3 & 13.0 & 25.4 & 30.3 & 14.2 & 4.8 & 12.3 \\
Subjects allied to & 66.3 & 7.6 & 42.2 & 27.5 & 3.3 & 2.8 & 16.5 \\
medicine & & & & & & & 3.3 \\
Multi-discipline & 51.1 & 8.9 & 31.1 & 21.1 & 2.3 & 3.1 & 10.4 \\
Physical Sciences & 29.8 & 13.6 & 30.9 & 30.1 & 11.5 & 3.5 & 9.8 \\
Social Sciences & 47.9 & 4.7 & 46.5 & 34.6 & 3.1 & 1.4 & \\
\hline
\end{tabular}


TABLE 4.

ORDERED PROBIT RESULTS

\begin{tabular}{|c|c|c|c|c|}
\hline \multirow[b]{2}{*}{ Variable } & \multicolumn{2}{|c|}{ Female Students } & \multicolumn{2}{|c|}{ Male Students } \\
\hline & Coefficient & T-ratio & Coefficient & T-ratio \\
\hline Constant & -2.3934 & -23.17 & -1.9128 & -19.793 \\
\hline Age & 0.19549 & 37.176 & 0.17203 & 35.028 \\
\hline Age Squared & $-2.38 \mathrm{E}-03$ & -33.657 & $-2.31 \mathrm{E}-03$ & -35.268 \\
\hline Male & - & - & - & - \\
\hline Born in the UK & 8.96E-03 & 0.408 & $6.21 \mathrm{E}-03$ & 0.328 \\
\hline Married & -0.24762 & -9.061 & -0.10027 & -3.186 \\
\hline \multicolumn{5}{|l|}{$\begin{array}{l}\text { School Type (omitted group }= \\
\text { comprehensive school) }\end{array}$} \\
\hline Others & $2.40 \mathrm{E}-03$ & 0.087 & $3.66 \mathrm{E}-02$ & 1.505 \\
\hline Technical & $-2.37 \mathrm{E}-02$ & -0.471 & $-2.63 \mathrm{E}-02$ & -0.622 \\
\hline Grammar & $-8.91 \mathrm{E}-03$ & -0.404 & $-3.60 \mathrm{E}-02$ & -1.811 \\
\hline Independent & $-7.50 \mathrm{E}-02$ & -4.258 & -0.13213 & -8.53 \\
\hline Sixth Form College & $-5.29 \mathrm{E}-02$ & -2.395 & $-8.69 \mathrm{E}-02$ & -4.297 \\
\hline Scotish Highers Score & $6.92 \mathrm{E}-02$ & 10.905 & $7.48 \mathrm{E}-02$ & 14.194 \\
\hline A Level Score & 4.74E-02 & 38.52 & $5.25 \mathrm{E}-02$ & 50.652 \\
\hline \multicolumn{5}{|l|}{$\begin{array}{l}\text { Main entry qualification (omitted } \\
\text { category }=\text { A-levels } / \text { Scottish Highers) }\end{array}$} \\
\hline No Qualifications & -0.38508 & -12.221 & -0.49527 & -17.207 \\
\hline GCE & -0.38539 & -12.143 & -0.68637 & -25.027 \\
\hline \multicolumn{5}{|l|}{$\begin{array}{l}\text { Subject }(\text { omitted group }= \\
\text { Business } / \text { Finance })\end{array}$} \\
\hline Subjects related to medicine & $-7.01 \mathrm{E}-02$ & -1.85 & $-8.17 \mathrm{E}-02$ & -1.77 \\
\hline Biological Science & 2.47E-02 & 0.766 & 3.83E-02 & 1.163 \\
\hline Agriculture \& Veterinary Sciences & -0.42537 & -8.356 & -0.29569 & -5.75 \\
\hline Physical Sciences & $-7.17 \mathrm{E}-02$ & -2.064 & $-1.91 \mathrm{E}-02$ & -0.659 \\
\hline Mathematical Sciences & -0.32442 & -9.108 & -0.17815 & -6.129 \\
\hline Engineering \& Technology & -0.1173 & -3.046 & $-8.54 \mathrm{E}-02$ & -3.09 \\
\hline Architecture \& Related & -0.42326 & -6.942 & $-6.68 \mathrm{E}-02$ & -1.475 \\
\hline Social Sciences & -0.14789 & -4.907 & $-1.04 \mathrm{E}-02$ & -0.367 \\
\hline Information Sciences & 0.3065 & 3.388 & $-3.19 \mathrm{E}-02$ & -0.271 \\
\hline Languages & -0.16964 & -5.634 & $4.53 \mathrm{E}-02$ & 1.421 \\
\hline Humanities & -0.12197 & -3.543 & 0.12256 & 3.728 \\
\hline Creative Arts & $-6.14 \mathrm{E}-02$ & -1.469 & 3.49E-02 & 0.768 \\
\hline Education & -0.28142 & -5.929 & -0.16897 & -2.484 \\
\hline Multi-discipline & -0.39412 & -10.91 & -0.27642 & -7.842 \\
\hline \multicolumn{5}{|l|}{$\begin{array}{l}\text { Parental Occupation (omitted } \\
\text { category = managerial and } \\
\text { professional) }\end{array}$} \\
\hline Clerical & $-5.70 \mathrm{E}-02$ & -2.402 & $-2.23 \mathrm{E}-02$ & -1.079 \\
\hline Services & -0.12112 & -4.518 & $-4.80 \mathrm{E}-02$ & -2.169 \\
\hline Manual & -0.14689 & -7.681 & $-4.20 \mathrm{E}-02$ & -2.641 \\
\hline Not specified & -0.42007 & -19.986 & -0.32956 & -17.41 \\
\hline \multicolumn{5}{|l|}{ Institutional Variables } \\
\hline $\begin{array}{r}\text { Percentage of income from research } \\
\text { contracts/grants }\end{array}$ & $1.65 \mathrm{E}-02$ & 8.61 & $1.33 \mathrm{E}-02$ & 7.832 \\
\hline $\begin{array}{r}\text { Percentage of departments graded } \\
\text { 'excellent' in TQA }\end{array}$ & $1.29 \mathrm{E}-03$ & 2.766 & $5.74 \mathrm{E}-04$ & 1.387 \\
\hline Number of Students & 8.19E-07 & 0.347 & $-1.29 \mathrm{E}-06$ & -0.611 \\
\hline Staff/Student Ratio & 3.2465 & 3.961 & 1.7045 & 2.43 \\
\hline
\end{tabular}




\begin{tabular}{|c|c|c|c|c|}
\hline \multicolumn{5}{|l|}{ Table 4 continued } \\
\hline \multicolumn{5}{|l|}{ Institutional Variables (continued) } \\
\hline Expenditure per Student & $-3.26 \mathrm{E}-02$ & -9.22 & $-1.95 \mathrm{E}-02$ & -7.851 \\
\hline Library spending per student & $2.72 \mathrm{E}-02$ & 0.601 & 0.26559 & 6.955 \\
\hline MU( 1) & 0.12046 & 27.62 & 0.19056 & 40.31 \\
\hline MU( 2) & 0.28572 & 45.542 & 0.48907 & 71.743 \\
\hline MU(3) & 1.232 & 123.722 & 1.3876 & 152.071 \\
\hline MU( 4) & 2.8983 & 201.187 & 2.6631 & 222.025 \\
\hline $\mathrm{N}$ & 3366 & & 40849 & \\
\hline log-likelihood & -43065.5 & & -59221.80 & \\
\hline chi-squared & 6631.55 & & 7768.92 & \\
\hline
\end{tabular}


TABLE 5.

ACTUAL AND PREDICTED PROBABILITIES OF GETTING A DEGREE CLASS

\begin{tabular}{|c|c|c|c|c|c|c|}
\hline & \multicolumn{2}{|c|}{ Actual probability } & \multicolumn{4}{|c|}{$\begin{array}{l}\text { Separate male/female regression } \\
\text { Predicted probability }\end{array}$} \\
\hline & Female & Male & $\begin{array}{c}\text { Female using } \\
\text { female } \\
\text { equation }\end{array}$ & $\begin{array}{l}\text { Male using } \\
\text { male equation }\end{array}$ & $\begin{array}{l}\text { Female using } \\
\text { male equation }\end{array}$ & $\begin{array}{c}\text { Male using } \\
\text { female } \\
\text { equation }\end{array}$ \\
\hline First & 0.064 & 0.0979 & 0.0473 & 0.0769 & 0.0730 & 0.0504 \\
\hline Two-one & 0.4427 & 0.3534 & 0.4506 & 0.3631 & 0.3562 & 0.4596 \\
\hline Two-two & 0.2958 & 0.3020 & 0.3287 & 0.3326 & 0.3351 & 0.3243 \\
\hline Third & 0.0361 & 0.0746 & 0.0390 & 0.0796 & 0.0815 & 0.0378 \\
\hline Others & 0.0232 & 0.0386 & 0.0243 & 0.0397 & 0.0409 & 0.0235 \\
\hline Fail/drop-out & 0.1382 & 0.1335 & 0.1099 & 0.1081 & 0.1133 & 0.1044 \\
\hline
\end{tabular}

TABLE 6.

DECOMPOSITION OF MALE-FEMALE DIFFERENCE IN ACADEMIC ACHIEVEMENT

\begin{tabular}{|l|l|}
\hline Expected male grade & 3.1273 \\
Expected female grade & 3.1624 \\
\hline Equation 3 & - \\
Explained variation & $0.0346=21.24 \%$ of total variation \\
Unexplained variation & $0.1283=78.76 \%$ of total variation \\
Total variation & 0.1629 \\
\hline Equation 4 & - \\
Explained variation & $0.0351=21.42 \%$ of total variation \\
Unexplained variation & $0.1288=78.58 \%$ of total variation \\
Total variation & 0.1639 \\
\hline
\end{tabular}


TABLE 7

PREDICTED PROBABILITY OF GETTING A DEGREE CLASS FOR STUDENTS WITH MAXIMUM A-LEVEL POINTS

\begin{tabular}{|c|c|c|}
\hline & Males & Females \\
\hline First & 0.2203 & 0.1483 \\
\hline Upper second & 0.4727 & 0.5849 \\
\hline Lower second & 0.2267 & 0.2085 \\
\hline Third & 0.0359 & 0.0169 \\
\hline Pass, Other & 0.0152 & 0.0096 \\
\hline $\begin{array}{c}\text { Non- } \\
\text { completion/fail }\end{array}$ & 0.0293 & 0.0318 \\
\hline
\end{tabular}

TABLE 8.

PREDICTED PROBABILITY OF GETTING A DEGREE CLASS BY SUBJECTS

\begin{tabular}{|c|c|c|c|c|c|c|c|c|c|c|c|c|}
\hline & \multicolumn{2}{|c|}{$\begin{array}{l}\text { Business } \\
\text { /Finance }\end{array}$} & \multicolumn{2}{|c|}{$\begin{array}{l}\text { Subjects } \\
\text { related to } \\
\text { medicine }\end{array}$} & \multicolumn{2}{|c|}{$\begin{array}{l}\text { Physical } \\
\text { Sciences }\end{array}$} & \multicolumn{2}{|c|}{$\begin{array}{l}\text { Mathematical } \\
\text { Sciences }\end{array}$} & \multicolumn{2}{|c|}{$\begin{array}{l}\text { Engineering \& } \\
\text { Technology }\end{array}$} & \multicolumn{2}{|c|}{$\begin{array}{l}\text { Agriculture \& } \\
\text { Veterinary } \\
\text { Sciences }\end{array}$} \\
\hline & M & $\mathrm{F}$ & M & $\mathrm{F}$ & M & $\mathrm{F}$ & M & $\mathrm{F}$ & M & $\mathrm{F}$ & M & $\mathrm{F}$ \\
\hline First & 0.083 & 0.063 & 0.083 & 0.055 & 0.081 & 0.054 & 0.081 & 0.032 & 0.082 & 0.049 & 0.047 & 0.025 \\
\hline Two-one & 0.374 & 0.491 & 0.353 & 0.471 & 0.369 & 0.471 & 0.328 & 0.393 & 0.353 & 0.457 & 0.297 & 0.361 \\
\hline Two-two & 0.328 & 0.306 & 0.336 & 0.318 & 0.33 & 0.318 & 0.342 & 0.351 & 0.336 & 0.325 & 0.346 & 0.358 \\
\hline Third & 0.076 & 0.033 & 0.082 & 0.036 & 0.078 & 0.036 & 0.088 & 0.046 & 0.082 & 0.038 & 0.096 & 0.056 \\
\hline Other & 0.037 & 0.021 & 0.041 & 0.022 & 0.038 & 0.022 & 0.046 & 0.029 & 0.041 & 0.023 & 0.051 & 0.033 \\
\hline $\begin{array}{c}\text { Fail/ } \\
\text { drop-out }\end{array}$ & 0.100 & 0.085 & 0.115 & 0.097 & 0.103 & 0.097 & 0.135 & 0.148 & 0.116 & 0.106 & 0.162 & 0.173 \\
\hline
\end{tabular}

Table 8 continued

\begin{tabular}{|c|c|c|c|c|c|c|c|c|c|c|}
\hline & \multicolumn{2}{|c|}{$\begin{array}{l}\text { Biological } \\
\text { Sciences } \\
\end{array}$} & \multicolumn{2}{|c|}{$\begin{array}{l}\text { Multi- } \\
\text { discipline }\end{array}$} & \multicolumn{2}{|c|}{ Creative Arts } & \multicolumn{2}{|c|}{$\begin{array}{l}\text { Information } \\
\text { Sciences }\end{array}$} & \multicolumn{2}{|c|}{$\begin{array}{l}\text { Architecture } \\
\& \text { Related }\end{array}$} \\
\hline & $\mathrm{M}$ & $\mathrm{F}$ & $\mathrm{M}$ & $\mathrm{F}$ & $\mathrm{M}$ & $\mathrm{F}$ & $\mathrm{M}$ & $\mathrm{F}$ & $\mathrm{M}$ & $\mathrm{F}$ \\
\hline First & 0.090 & 0.066 & 0.074 & 0.025 & 0.079 & 0.110 & 0.089 & 0.056 & 0.049 & 0.027 \\
\hline Two-one & 0.383 & 0.498 & 0.357 & 0.361 & 0.366 & 0.560 & 0.382 & 0.474 & 0.302 & 0.371 \\
\hline Two-two & 0.324 & 0.302 & 0.335 & 0.358 & 0.332 & 0.247 & 0.324 & 0.317 & 0.346 & 0.356 \\
\hline Third & 0.074 & 0.033 & 0.081 & 0.050 & 0.079 & 0.022 & 0.074 & 0.036 & 0.095 & 0.049 \\
\hline Other & 0.036 & 0.020 & 0.041 & 0.033 & 0.039 & 0.013 & 0.036 & 0.022 & 0.050 & 0.031 \\
\hline Fail/ & 0.094 & 0.082 & 0.112 & 0.173 & 0.106 & 0.047 & 0.094 & 0.096 & 0.158 & 0.165 \\
\hline Drop-out & & & & & & & & & & \\
\hline
\end{tabular}

Table 8 continued

\begin{tabular}{|clllllllll|}
\hline & \multicolumn{3}{l}{$\begin{array}{l}\text { Social } \\
\text { Sciences }\end{array}$} & & \multicolumn{2}{l}{ Languages } & \multicolumn{2}{l|}{ Humanities } & \multicolumn{2}{l|}{ Education } \\
& $\mathrm{M}$ & $\mathrm{F}$ & $\mathrm{M}$ & $\mathrm{F}$ & $\mathrm{M}$ & $\mathrm{F}$ & $\mathrm{M}$ & $\mathrm{F}$ \\
\hline First & 0.082 & 0.047 & 0.091 & 0.045 & 0.09 & 0.049 & 0.046 & 0.063 \\
Two-one & 0.371 & 0.448 & 0.385 & 0.441 & 0.402 & 0.456 & 0.331 & 0.491 \\
Two-two & 0.329 & 0.329 & 0.323 & 0.332 & 0.313 & 0.326 & 0.342 & 0.306 \\
Third & 0.077 & 0.039 & 0.073 & 0.04 & 0.067 & 0.038 & 0.088 & 0.033 \\
Other & 0.038 & 0.025 & 0.036 & 0.025 & 0.030 & 0.024 & 0.045 & 0.021 \\
Fail/ & 0.102 & 0.111 & 0.092 & 0.115 & 0.08 & 0.106 & 0.133 & 0.086 \\
drop-out & & & & & & & & \\
\hline
\end{tabular}


TABLE 9 -

PREDICTED PROBABILITIES, FEMALE STUDENTS BY UNIVERSITY

\begin{tabular}{|c|c|c|c|c|c|c|}
\hline & $\begin{array}{l}\text { dropout/ } \\
\text { fail }\end{array}$ & other & third & two-two & \multicolumn{2}{|c|}{ two-one first } \\
\hline 1 & 0.076 & 0.019 & 0.031 & 0.295 & 0.507 & 0.071 \\
\hline 2 & 0.069 & 0.018 & 0.029 & 0.286 & 0.520 & 0.078 \\
\hline 3 & 0.118 & 0.026 & 0.041 & 0.335 & 0.438 & 0.043 \\
\hline 4 & 0.108 & 0.024 & 0.039 & 0.327 & 0.454 & 0.049 \\
\hline 5 & 0.120 & 0.026 & 0.041 & 0.336 & 0.435 & 0.042 \\
\hline 6 & 0.154 & 0.030 & 0.047 & 0.352 & 0.386 & 0.030 \\
\hline 7 & 0.114 & 0.025 & 0.040 & 0.331 & 0.445 & 0.046 \\
\hline 9 & 0.105 & 0.024 & 0.038 & 0.324 & 0.459 & 0.050 \\
\hline 10 & 0.096 & 0.022 & 0.036 & 0.317 & 0.474 & 0.056 \\
\hline 11 & 0.098 & 0.023 & 0.037 & 0.319 & 0.470 & 0.054 \\
\hline 12 & 0.127 & 0.027 & 0.043 & 0.340 & 0.424 & 0.039 \\
\hline 13 & 0.114 & 0.025 & 0.040 & 0.332 & 0.445 & 0.045 \\
\hline 14 & 0.119 & 0.026 & 0.041 & 0.335 & 0.436 & 0.043 \\
\hline 15 & 0.118 & 0.026 & 0.041 & 0.335 & 0.438 & 0.043 \\
\hline 16 & 0.098 & 0.023 & 0.036 & 0.319 & 0.470 & 0.054 \\
\hline 17 & 0.111 & 0.025 & 0.039 & 0.330 & 0.449 & 0.047 \\
\hline 18 & 0.099 & 0.023 & 0.037 & 0.320 & 0.468 & 0.054 \\
\hline 20 & 0.110 & 0.024 & 0.039 & 0.329 & 0.451 & 0.047 \\
\hline 21 & 0.096 & 0.022 & 0.036 & 0.317 & 0.473 & 0.055 \\
\hline 22 & 0.105 & 0.024 & 0.038 & 0.325 & 0.459 & 0.050 \\
\hline 23 & 0.126 & 0.027 & 0.042 & 0.339 & 0.426 & 0.040 \\
\hline 24 & 0.111 & 0.025 & 0.039 & 0.329 & 0.449 & 0.047 \\
\hline 25 & 0.125 & 0.027 & 0.042 & 0.339 & 0.428 & 0.040 \\
\hline 26 & 0.103 & 0.023 & 0.038 & 0.323 & 0.461 & 0.051 \\
\hline 27 & 0.089 & 0.021 & 0.034 & 0.310 & 0.485 & 0.060 \\
\hline 28 & 0.109 & 0.024 & 0.039 & 0.328 & 0.452 & 0.048 \\
\hline 30 & 0.108 & 0.024 & 0.039 & 0.327 & 0.455 & 0.049 \\
\hline 31 & 0.115 & 0.025 & 0.040 & 0.332 & 0.443 & 0.045 \\
\hline 32 & 0.112 & 0.025 & 0.039 & 0.330 & 0.448 & 0.047 \\
\hline 33 & 0.112 & 0.025 & 0.040 & 0.330 & 0.447 & 0.046 \\
\hline 34 & 0.105 & 0.024 & 0.038 & 0.325 & 0.459 & 0.050 \\
\hline 35 & 0.113 & 0.025 & 0.040 & 0.331 & 0.447 & 0.046 \\
\hline 37 & 0.107 & 0.024 & 0.039 & 0.327 & 0.455 & 0.049 \\
\hline 42 & 0.104 & 0.024 & 0.038 & 0.324 & 0.460 & 0.050 \\
\hline 44 & 0.117 & 0.025 & 0.040 & 0.334 & 0.440 & 0.044 \\
\hline 45 & 0.113 & 0.025 & 0.040 & 0.331 & 0.446 & 0.046 \\
\hline 46 & 0.113 & 0.025 & 0.040 & 0.331 & 0.445 & 0.046 \\
\hline 47 & 0.155 & 0.030 & 0.047 & 0.353 & 0.385 & 0.030 \\
\hline 48 & 0.149 & 0.030 & 0.046 & 0.351 & 0.392 & 0.032 \\
\hline 49 & 0.125 & 0.027 & 0.042 & 0.339 & 0.427 & 0.040 \\
\hline 50 & 0.132 & 0.028 & 0.043 & 0.343 & 0.417 & 0.038 \\
\hline 51 & 0.125 & 0.027 & 0.042 & 0.339 & 0.427 & 0.040 \\
\hline
\end{tabular}


TABLE 9 (CONTINUED)

PREDICTED PROBABILITIES BY UNIVERSITY, MALE STUDENTS

\begin{tabular}{|c|c|c|c|c|c|c|}
\hline & dropout/fail & other & third & two-two & two-one & first \\
\hline 1 & 0.068 & 0.029 & 0.061 & 0.300 & 0.421 & 0.121 \\
\hline 2 & 0.053 & 0.024 & 0.053 & 0.279 & 0.443 & 0.148 \\
\hline 3 & 0.092 & 0.035 & 0.073 & 0.323 & 0.386 & 0.092 \\
\hline 4 & 0.102 & 0.038 & 0.077 & 0.330 & 0.371 & 0.082 \\
\hline 5 & 0.118 & 0.042 & 0.083 & 0.337 & 0.350 & 0.069 \\
\hline 6 & 0.115 & 0.041 & 0.082 & 0.336 & 0.355 & 0.072 \\
\hline 7 & 0.117 & 0.042 & 0.083 & 0.337 & 0.351 & 0.070 \\
\hline 9 & 0.111 & 0.040 & 0.081 & 0.334 & 0.359 & 0.075 \\
\hline 10 & 0.096 & 0.037 & 0.075 & 0.326 & 0.380 & 0.087 \\
\hline 11 & 0.100 & 0.038 & 0.076 & 0.328 & 0.374 & 0.084 \\
\hline 12 & 0.121 & 0.043 & 0.084 & 0.338 & 0.347 & 0.068 \\
\hline 13 & 0.116 & 0.041 & 0.082 & 0.336 & 0.353 & 0.071 \\
\hline 14 & 0.117 & 0.042 & 0.083 & 0.337 & 0.352 & 0.071 \\
\hline 15 & 0.123 & 0.043 & 0.085 & 0.339 & 0.344 & 0.067 \\
\hline 16 & 0.105 & 0.039 & 0.078 & 0.331 & 0.368 & 0.080 \\
\hline 17 & 0.112 & 0.041 & 0.081 & 0.335 & 0.358 & 0.074 \\
\hline 18 & 0.102 & 0.038 & 0.077 & 0.330 & 0.371 & 0.082 \\
\hline 20 & 0.110 & 0.040 & 0.080 & 0.333 & 0.361 & 0.076 \\
\hline 21 & 0.100 & 0.038 & 0.076 & 0.328 & 0.375 & 0.084 \\
\hline 22 & 0.108 & 0.040 & 0.080 & 0.333 & 0.363 & 0.077 \\
\hline 23 & 0.120 & 0.043 & 0.084 & 0.338 & 0.347 & 0.068 \\
\hline 24 & 0.115 & 0.041 & 0.082 & 0.336 & 0.354 & 0.072 \\
\hline 25 & 0.117 & 0.042 & 0.083 & 0.337 & 0.351 & 0.070 \\
\hline 26 & 0.105 & 0.039 & 0.079 & 0.331 & 0.367 & 0.079 \\
\hline 27 & 0.092 & 0.036 & 0.073 & 0.323 & 0.385 & 0.091 \\
\hline 28 & 0.110 & 0.040 & 0.080 & 0.334 & 0.361 & 0.075 \\
\hline 30 & 0.113 & 0.041 & 0.081 & 0.335 & 0.357 & 0.073 \\
\hline 31 & 0.119 & 0.042 & 0.084 & 0.337 & 0.349 & 0.069 \\
\hline 32 & 0.114 & 0.041 & 0.082 & 0.335 & 0.355 & 0.073 \\
\hline 33 & 0.113 & 0.041 & 0.082 & 0.335 & 0.356 & 0.073 \\
\hline 34 & 0.103 & 0.038 & 0.078 & 0.330 & 0.371 & 0.081 \\
\hline 35 & 0.118 & 0.042 & 0.083 & 0.337 & 0.350 & 0.070 \\
\hline 37 & 0.112 & 0.041 & 0.081 & 0.334 & 0.358 & 0.074 \\
\hline 42 & 0.107 & 0.039 & 0.079 & 0.332 & 0.364 & 0.078 \\
\hline 44 & 0.121 & 0.043 & 0.084 & 0.338 & 0.346 & 0.067 \\
\hline 45 & 0.113 & 0.041 & 0.082 & 0.335 & 0.356 & 0.073 \\
\hline 46 & 0.115 & 0.041 & 0.082 & 0.336 & 0.354 & 0.072 \\
\hline 47 & 0.138 & 0.047 & 0.090 & 0.343 & 0.325 & 0.058 \\
\hline 48 & 0.145 & 0.048 & 0.092 & 0.344 & 0.317 & 0.054 \\
\hline 49 & 0.127 & 0.044 & 0.086 & 0.340 & 0.338 & 0.064 \\
\hline 50 & 0.133 & 0.045 & 0.088 & 0.342 & 0.332 & 0.061 \\
\hline 51 & 0.125 & 0.044 & 0.086 & 0.339 & 0.342 & 0.066 \\
\hline
\end{tabular}


APPENDIX

Variable Descriptions

(All data from the USR data base unless otherwise stated)

\begin{tabular}{|c|c|}
\hline Variable & Description \\
\hline Age & The age of the student. \\
\hline A level score & $\begin{array}{l}\text { Student's 'A' Level point score calculated from } \\
\text { best three passes. }\end{array}$ \\
\hline Scottish Highers & $\begin{array}{l}\text { Student's Scottish Highers point score calculated } \\
\text { from best five passes. }\end{array}$ \\
\hline Married & ' 1 ' if the student was married; ' 0 ' otherwise. \\
\hline Born in UK & ' 1 ' if the student was born in the UK, ' 0 ' otherwise \\
\hline \multicolumn{2}{|l|}{ School Type } \\
\hline Comprehensive & $\begin{array}{l}\text { ' } 1 \text { ' if the student attended a comprehensive } \\
\text { school; ' } 0 \text { ' otherwise. }\end{array}$ \\
\hline Secondary/technical & $\begin{array}{l}\text { ' } 1 \text { ' if the student attended a secondary or } \\
\text { technical school or ; ' } 0 \text { ' otherwise. }\end{array}$ \\
\hline Independent & $\begin{array}{l}\text { ' } 1 \text { ' if the student attended an independent school; } \\
\text { ' } 0 \text { ' otherwise. }\end{array}$ \\
\hline No school type given & ' 1 ' if no school type was specified; '0' otherwise. \\
\hline $6^{\text {th }}$ form college & $\begin{array}{l}\text { ' } 1 \text { ' if the student attended a sixth form college; ' } 0 \text { ' } \\
\text { otherwise. }\end{array}$ \\
\hline \multicolumn{2}{|l|}{ Entry qualifications } \\
\hline no qualifications & $\begin{array}{l}\text { ' } 1 \text { ' if the student had no previous qualifications; } \\
\text { ' } 0 \text { ' otherwise. }\end{array}$ \\
\hline GCE & $\begin{array}{l}\text { ' } 1 \text { ' if the entry qualification was A-level or } \\
\text { Scottish Highers; '0' otherwise. }\end{array}$ \\
\hline born in UK & $\begin{array}{l}\text { ' } 1 \text { ' if the student was born in the UK; ' } 0 \text { ' } \\
\text { otherwise. }\end{array}$ \\
\hline \multicolumn{2}{|l|}{ Parental Occupation } \\
\hline Professional and Managerial & $\begin{array}{l}\text { ' } 1 \text { ' if the student's parents were employed in a } \\
\text { professional or managerial occupation such as } \\
\text { accountants, managers, solicitors etc or a } \\
\text { technical occupation such as engineers, scientists, } \\
\text { technicians, draughtsmen etc; ' } 0 \text { ' otherwise. }\end{array}$ \\
\hline Clerical & $\begin{array}{l}\text { ' } 1 \text { ' if the student's parents were employed in a } \\
\text { clerical or secretarial occupation such as } \\
\text { receptionists, clerks, cashiers etc; ' } 0 \text { ' otherwise.. }\end{array}$ \\
\hline Services & $\begin{array}{l}\text { ' } 1 \text { ' if the student's parents were employed in a } \\
\text { service sector occupation such as policemen, shop } \\
\text { assistants, caretakers, bookmakers, etc; '0' } \\
\text { otherwise. }\end{array}$ \\
\hline Manual & $\begin{array}{l}\text { ' } 1 \text { ' if the student's parents were employed in a } \\
\text { manual occupation such as carpenters, joiners, } \\
\text { toolmakers, electrical engineers, welders, etc; ' } 0 \text { ' } \\
\text { otherwise. }\end{array}$ \\
\hline Not Specified & $\begin{array}{l}\text { '1' if the student's parents occupations was not } \\
\text { specified; '0' otherwise. }\end{array}$ \\
\hline
\end{tabular}




\begin{tabular}{|c|c|}
\hline Degree subject & \\
\hline Subjects related to Medicine & $\begin{array}{l}\text { ' } 1 \text { ' if the student studied a subject related to } \\
\text { medicine such as pharmacy, anatomy, nursing, } \\
\text { medical technology, etc; ' } 0 \text { ' otherwise. }\end{array}$ \\
\hline Biological sciences & $\begin{array}{l}\text { ' } 1 \text { ' if the student studied a biological science such } \\
\text { as biology, zoology, genetics, biochemistry etc; } \\
\text { ' } 0 \text { ' otherwise. }\end{array}$ \\
\hline Agriculture \& Veterinary Sciences & $\begin{array}{l}\text { ' } 1 \text { ' if the student studied agriculture or a related } \\
\text { subject such as agriculture, forestry, food science, } \\
\text { veterinary studies etc; ' } 0 \text { ' otherwise. }\end{array}$ \\
\hline Physical sciences & $\begin{array}{l}\text { ' } 1 \text { ' if the student studied a physical science such } \\
\text { as chemistry, physics, astronomy, geology etc; ' } 0 \text { ' } \\
\text { otherwise. }\end{array}$ \\
\hline Mathematical Sciences & $\begin{array}{l}\text { ' } 1 \text { ' if the student studied mathematics or similar } \\
\text { course such as statistics or computer science; ' } 0 \text { ' } \\
\text { otherwise. }\end{array}$ \\
\hline Engineering \& Technology & $\begin{array}{l}\text { ' } 1 \text { ' if the student studied an engineering course } \\
\text { such as civil engineering, mechanical engineering, } \\
\text { electrical engineering etc or a related course such } \\
\text { as minerals technology, metallurgy, materials } \\
\text { technology; ' } 0 \text { ' otherwise. }\end{array}$ \\
\hline Architecture \& Related & $\begin{array}{l}\text { ' } 1 \text { ' if the student studied Architecture or related } \\
\text { subject such as town and country planning, } \\
\text { building, environmental technologies; ' } 0 \text { ' } \\
\text { otherwise. }\end{array}$ \\
\hline Social sciences & $\begin{array}{l}\text { ' } 1 \text { ' if the student studied a social science such as } \\
\text { economics, sociology, social policy, law, politics; } \\
\text { ' } 0 \text { ' otherwise. }\end{array}$ \\
\hline Information Sciences & $\begin{array}{l}\text { ' } 1 \text { ' if the student studied a mass communication } \\
\text { and documentation course such as librarianship, } \\
\text { information science, communication studies and } \\
\text { media studies; '0' otherwise. }\end{array}$ \\
\hline Business/Finance (omitted category) & $\begin{array}{l}\text { ' } 1 \text { ' if the student studied a business or finance } \\
\text { course such as accountancy, financial } \\
\text { management, operational research, marketing etc; } \\
\text { ' } 0 \text { ' otherwise. }\end{array}$ \\
\hline Languages & $\begin{array}{l}\text { ' } 1 \text { ' if the student studied a language including } \\
\text { foreign languages, linguistics and English } \\
\text { literature; ' } 0 \text { ' otherwise. }\end{array}$ \\
\hline Humanities & $\begin{array}{l}\text { ' } 1 \text { ' if the student studied a humanities subject such } \\
\text { as history philosophy, theology, archaeology etc; } \\
\text { ' } 0 \text { ' otherwise. }\end{array}$ \\
\hline Creative Arts & $\begin{array}{l}\text { ' } 1 \text { ' if the student studied an arts subject such as } \\
\text { fine arts, design studies, music, drama, etc ; ' } 0 \text { ' } \\
\text { otherwise. }\end{array}$ \\
\hline Education & $\begin{array}{l}\text { ' } 1 \text { ' if the student studied an education course such } \\
\text { as teacher training, academic studies in education } \\
\text { and management in education ; ' } 0 \text { ' otherwise. }\end{array}$ \\
\hline Multi-Discipline & ' 1 ' if the student studied a multi-disciplinary \\
\hline
\end{tabular}




\begin{tabular}{|l|l|}
\hline & course; '0’ otherwise. \\
\hline Institutional Variables & \\
\hline \% university income from research grants & $\begin{array}{l}\text { The percentage of university income which came } \\
\text { from research grants. Source: University } \\
\text { Statistics 1992-93 Volume 3 Table 1. }\end{array}$ \\
\hline Teaching quality assessment performance & $\begin{array}{l}\text { The proportion of departments rated as excellent } \\
\text { in TQA carried out by the HEHC and available on } \\
\text { the QAA website - http://www.qaa.ac.uk }\end{array}$ \\
\hline Staff-student ratio & $\begin{array}{l}\text { The ratio of staff to students at the students } \\
\text { university. Source: University Statistics 1992-93 } \\
\text { Volume 1 Tables 14 and 30. }\end{array}$ \\
\hline Total expenditure per student & $\begin{array}{l}\text { The ratio of the university's total income to the } \\
\text { number of students. Source: University Statistics } \\
\text { 1992-93 Volume 3 Table 7. }\end{array}$ \\
\hline Library expenditure per student & $\begin{array}{l}\text { The ratio of total library expenditure to the } \\
\text { number of students. Source: University Statistics } \\
\text { 1992-93 Volume 3 Table 7. }\end{array}$ \\
\hline Number of Students & $\begin{array}{l}\text { The total number of undergraduates at the } \\
\text { institutions. } \\
\text { Source: University Statistics 1992-93 Volume 1 } \\
\text { Table 14. }\end{array}$ \\
\hline
\end{tabular}




\section{NOTES}

${ }^{1}$ The papers by Dolton, Greenaway and Vignoles (1997) and Johnes (1997) provide recent discussions of the Dearing Inquiry.

${ }^{2}$ For official bulletins containing some relevant information on gender comparisons see 'Natural Curriculum Assessments of 7, 11 and 14 year olds in England - 1998', Statistical Bulletin, Issue No. 6, April 1999, HMSO, Statistics of Education, GCSE / GNVQ and GCE A / AS level and advanced GNVQ examination results 1998/99, England, Statistical Bulletin, Issue No. 04/00, May 2000, HMSO, School Attainment and Qualifications of School Leavers in Scotland: 1997-98, Statistical Bulletin, Scottish Executive, Edinburgh, $24^{\text {th }}$ August 1999.

${ }^{3}$ The absence of comparable data means that we cannot carry out a similar analysis for the period since 1993, which would enable 'old' and 'new' universities to be compared.

${ }^{4}$ The conditions under which the USR data is accessed do not allow individual universities to be identified.

${ }^{5}$ The data do not contain information on the gender mix of staff by department and institution.

${ }^{6}$ Mellanby et al (2000) use an alternative measure of ability/aptitude, the AH6 Group test of High Intelligence. They find that the correlation between this measure and degree performance is similar to that between A-level score and degree performance.

${ }^{7}$ One possibility would be to compare students examined using blind marking with those that are not. However, anecdotal evidence suggests that blind marking was not very common in 1993 and that it would be impossible to identify those specific departments that had implemented it.

${ }^{8}$ It should be noted that the probabilities shown in Table 5 are lower than those in Table 1 because the former also includes people who do not complete their degree whereas the latter is based only on graduates. 